\title{
Phrasal Verbs Found In the Movie "Finding Dory" and Their Translations Into Indonesian
}

\author{
Ni Made Dewi Satya Utami \\ English Department, Faculty of Arts, Udayana University \\ [satyautami1@gmail.com]
}

\begin{abstract}
Abstrak
Tujuan dari penelitian ini adalah untuk menganalisis jenis prosedur terjemahan dari phrasal verbs dalam teks di film Finding Dory oleh Andrew Staton dan menggambarkan adanya penyimpangan informasi dari ungkapan kata kerja dalam bahasa target. Jenis penelitian ini termasuk penelitian deskriptif kualitatif. Data penelitian adalah kalimat yang mengandung ungkapan kata kerja yang menerapkan jenis prosedur terjemahan dan penyimpangan infromasi pada teks di film yang berjudul Finding Dory. Metode pengumpulan data adalah metode dokumentasi dan teknik pengambilan data dan analisis data dilakukan dengan membandingkan ungkapan kata kerja antara bahasa sumber dan bahasa target pada teks di film Finding Dory. Hasil penelitian ini menunjukkan bahwa jenis prosedur penerjemahan yang banyak digunakan adalah transposisi dan modulasi. Adanya penyimpangan informasi yang ditemukan dalam terjemahan ungkapan kata kerja. Dari hasil penelitian, dapat disimpulkan bahwa ada perbedaan dalam hal pembentukan struktur kata antara bahasa sumber dan bahasa target, adanya perbedaan pandangan antara dua bahasa, dan dalam menerjemahkan antara bahasa sumber dan bahasa target mengakibatkan penyimpangan informasi yang tidak sama persis dengan bahasa sumber. Hal ini juga menyebabkan perubahan pesan dari kebenarannya.
\end{abstract}

\section{Kata kunci : Phrasal Verbs, Prosedur Terjemahan, Penyimpangan Informasi}

\begin{abstract}
The objectives of this research are to analyze the types of translation procedures of phrasal verb in the movie Finding Dory subtitle by Andrew Staton and describe the skewed information of phrasal verb found in the target language. The type of this research belongs to descriptive qualitative research. The data of the research are sentences containing phrasal verbs in the movie subtitle entitled Finding Dory. The method of collecting data was documentation method and note taking technique and the data were analyzed by comparing phrasal verbs between the source language and target language in the Movie Finding Dory subtitle. The result of this study shows that the types of translation procedures mostly used are transposition and modulation. There is skewed information found in the translation of phrasal verbs. From the result of the study, it can be concluded that there are differences in terms of structural formation of words between the source and the target language, different perspectives between two languages, and in translating
\end{abstract}


between $S L$ and TL resulting in the skewed information which is not the exact equivalent of the SL. It also causes distortion in the message.

\section{Keywords : Phrasal Verbs, Procedures of Translation, Skewing of Information}

\section{Background of the Study}

People use language as a tool to communicate and do conversation with others in a variety of purposes. By using language people can express their thought and feeling. Every country in the world has different languages and the different languages make people difficult to communicate with the other countries. In this case, translation is a media that is used for people to communicate.

Translation is a process of finding the textual equivalence of the source language in the target language to convey the meaning. According to Newmark (1988:7) translation is a craft consisting an attempt to replace a message and or statement in one language by the same message or statement in another language. The language that is going to be translated is called the source language (SL), whereas the language into which translation in done is called the target language (TL). Moreover, translation is one of the subjects learned by the students to acquire the target language. The students will face many difficulties because of the different systems between the source language (English) and the target language (Indonesia). In this case, the message or speech consists of words. The verb becomes the most important part of a sentence when used in communication.

Talking about translation from English into Indonesian, there are problems found in translating phrasal verbs. Phrasal verbs are verbs plus one or two 'particles'. The particles can be either prepositions or adverbs (Quirk, Randolph, 1985). In
English phrasal verbs, the meaning of the combination of verb and particle cannot be predicted in Indonesian.

Being interested in studying the English phrasal verbs that particular source genre can be found in a movie which contains conversation. The movie that is used in this research is entitled "Finding Dory". This movie is serving numerous numbers of phrasal verbs. This movie is not only for entertainment but also for a strategy to learn English individually, especially to learn phrasal verbs.

Referring to the details above, it builds up an interest to identify the types of translation procedures occurring in phrasal verbs as well as their translations in target language. Due to the fact there will be inevitable differences in terms of grammatical structure and point of view between SL and TL. Moreover, this study also discusses the skewed information of phrasal verbs that deviated or distorted in the target language.

\section{Problems of the Study}

a) What procedures are applied in translating the English phrasal verbs into Indonesian in the movie "Finding Dory"?

b) How does the skewed information take place in translation of the English phrasal verb in the "Finding Dory" movie?

\section{Aims of the Study}

a) To identify and describe the types of translation procedures used to translate English phrasal verbs into 
Indonesian found in the "Finding Dory" movie.

b) To describe the skewed information that takes place when translating English phrasal verbs into Indonesian found in "Finding Dory" movie.

\section{Research Method}

Writing methodology is an important role to be followed. In obtaining the data, the research method covers four points; those are data source, method and technique of collecting data, method and technique of analyzing data, and method and technique of presenting data.

\subsection{Data source}

Since this study involves two languages, the data sources were obtained in the English movie and Indonesian subtitle of the movie Finding Dory. The data source in English text were taken from the website

https://subscene.com/subtitles/findingdory/english/1433113. While, the data source in Indonesian were taken from the website

https://subscene.com/subtitles/findingdory/indonesian/1433227.

\subsection{Method and technique of collecting data}

The method of this study was conducted through documentation, library research, and note taking technique. Firstly, findint out the data by watching and reading the subtitle of the movie "Finding Dory" both in spoken English and in Indonesian. Then, identifying phrasal verbs found which are translated into different word classes in target language. Following the step above, the data were collected by note taking in order to find out the words in the subtitle of source language and target language. The next step was comparing the data found between source language and target language, followed by the last step which was conducted by listing and identifying the types of translation procedures applied and the skewed information found in the translations of phrasal verbs.

\subsection{Method and Technique of Analyzing \\ Data.}

The method that was used in analyzing the data is the descriptive qualitative method and the types of translation procedures used to translate the English phrasal verbs based on the theory purposed by Vinay and Darbelnet in Venuti (2000). This study also describes the skewed information when translating phrasal verbs in English into Indonesian based on the theory proposed by Nida (1975). The data were analyzed in terms of some steps.

After the data were classified, they were compared in order to compare and identify the English phrasal verbs in the movie "Finding Dory" and its Indonesian subtitle. Then, the types of translation procedures proposed by Vinay and Darbelnet in Venuti (2000) were used to analyze the data. The last step, the writer described the skewed information of English phrasal verbs into Indonesian using the theory proposed by Nida (1975).

\subsection{Method and Technique of Presenting Data}

The data were presented formally and informally using the method proposed by Sudaryanto (1993). He stated that the formal method deals with the way of presenting a topic by explaining using words to describe findings. The formal method means that data are analyzed using symbols, tables, diagrams, and figures. Whereas, informal presentation method is 
the result of the data analyzed by verbal description or explained by words (Sudayanto 1993:145).

The data were presented descriptively based on the theory by explaining and describing the phrasal verbs through some steps as follows :

The data found in the movie were collected and identified; the types of translation procedures applied was the theory proposed by Vinay and Darbelnet in Venuti (2000), which were presented in the form of paragraph.

Furthermore, the analysis describes the skewed information applicable as the basic principle of the translation proposed by Nida (1975).

\section{Result and discussion}

The data divides and describes based on the types of procedures of translation based on Vinay and Darlbernet (1958). In order to support the analysis in this study, the staging of the data was essentially according to "The Principle of Translation" by Nida (1975), emphasizing not only the procedures of translation but also the skewing information found in the target language.

\subsection{Procedures of Translation 5.1.1 Transposition}

Transposition is a process or method of translation which involves replacing one word class from SL into TL. In this situation, the translation process indicates replacing grammatical ways without changing the meaning or the message delivered.
Table 5.1 .1 of data 1

\begin{tabular}{lll}
\hline NO & \multicolumn{1}{c}{ SL } & \multicolumn{1}{c}{ TL } \\
\hline 1 & $\begin{array}{l}\text { Can you please } \\
\text { keep it down } \\
\text { over there? My } \\
\text { head hurts. }\end{array}$ & $\begin{array}{l}\text { Bisa tolong } \\
\text { pelankan } \\
\text { suaramu? } \\
\text { Kepalaku sakit. }\end{array}$ \\
& (Finding Dory, & (Finding Dory, \\
& 2016, & 2016, \\
& $00: 32: 12,098-$ & 00:32:12,098 - \\
& $00: 32: 15,388$ ) & $00: 32: 15,388$ )
\end{tabular}

The phrasal verb keep down is found in the example above which is formed by the verb keep and adverb down. The example of the phrasal verb keep down in table 5.1.1 of data (1) is a transitive phrasal verb, thus it shows it has a direct object. The meaning in the context of phrasal verb keep down is "to the level of noise lower and keep it lower" (Spears, 2005:372). Whereas, the phrasal verb keep down is translated into a simple verb pelankan in target language. Even though the phrasal verb keep down is translated into pelankan in target language, its meaning is the same and still compatible each other. Then, if we look at the process of translating the phrasal verb keep down into a verb pelankan in Indonesa, it shows replacing word class in TL without changing the message or the information. Therefore, this process of translation applied the procedure of translation of transposition.

\subsubsection{Modulation}

Modulation is a process of translation which occurs when there is a change of perspective or point of view in TL. It is a process of translation occurring when there is a change of perspective or point of view in TL. 
Table 5.1.2 of data 1

\begin{tabular}{lll}
\hline NO & \multicolumn{1}{c}{ SL } & \multicolumn{1}{c}{ TL } \\
\hline 1 & Okay. Guess & Baiklah, kita \\
& we'll hang out & ngobrol lain \\
& another & waktu. \\
& time. Don't be a & Jangan lupakan \\
& stranger, & aku... Ikan \\
Stranger. & asing... \\
& (Finding Dory, & (Finding Dory, \\
& 2016, & 2016, \\
& 00:06:01,612 - & 00:06:01,612 - \\
& 00:06:07,618) & 00:06:07,618) \\
\hline & The structure & of the transitive
\end{tabular}

phrasal verb hang out found in the data source is derived from the verb hang and adverb out. The phrasal verb in table 3.1.1 of data (1) is a transitive one because it takes an object. The combination of phrasal verb gives a new meaning in to "to spend a time in a place habitually" (Spears, 2005:281). The phrasal verb hang out is translated into Indonesian as a verb mengobrol in target language. According to KKBI, it means "mempercakapkan/memperbincangkan secara santai sesuatu yang tidak penting”.

In this case, the information or message of source language is not compatible and different from the meaning in target language. Moreover, the translation process results in a different point of view in Indonesia. On the other hand, the translation procedures used in this translation process is modulation.

\subsection{Skewed Information}

In the data source, there are found phrasal verbs which belong to skewed information, as we can see in the table below.
Table 5.2 of data 1

\begin{tabular}{lll}
\hline NO & \multicolumn{1}{c}{ SL } & \multicolumn{1}{c}{ TL } \\
\hline 1 & $\begin{array}{l}\text { Where'd you } \\
\text { grow up, }\end{array}$ & Kau darimana, \\
& Dory?
\end{tabular}

Dory?

$\begin{array}{ll} & \text { (Finding Dory, } \\ \text { (Finding } & 2016, \\ \text { Dory, 2016, } & 00: 09: 53,344 \text { - } \\ 00: 09: 53,344 & 00: 09: 54,684 \text { ) }\end{array}$

00:09:54,684)

Apart from the phrasal verbs found above, the phrasal verb grew up has also been found. This phrasal verb is derived from the verb grow and an adverb up. Here, the phrasal verb takes an object which means the phrasal verb grows up is a transitive phrasal verb. Furthermore, the combination of the phrasal verb grows up delivers a new meaning "to grow toward, to become mature" (Spears, 2005:275). Whereas, in the text, the phrasal verb grow $u p$ is translated as a pronoun darimana in Indonesian. As the explanation above, the phrasal verb grow up which is translated into darimana in Indonesia does have the same meaning and they are incompatible to each other due to the pronoun darimana which has different perspective in Indonesian. In this case, the process of translation is that there is no exact equivalent. In other words, we can say that the message of the source language is wrongly translated in the target language. We can conclude that the phrasal verb grow up in the example above sows skewing of information.

\section{Conclusion}

Based on the analysis, the research draws the following conclusions which can be done by both investigating from the types of translation procedures and skewed 
information found in the target language. These conclusions answer the problem statements of this study.

There are procedures of translation applied in translating the phrasal verbs occuring in the subtitle of the movie entitled "Finding Dory". The transposition and modulation procedures mostly found in the translation of phrasal verbs due to the fact that there are different grammatical structures or word classes, different perspectives or points of view in transferring the message from source language to target language. These differences, if they are not dealt with attentively, will cause the distortion of the meaning being transferred from the source to the target language.

The skewed information delivered from the source language to the target language occurs due to the fact that there is the difference between the culture of the SL and TL. The skewing refers in the non equivalence and distortion of the meaning.

\section{References}

Ambarawati, AA Istri, 2007. The Analysis of Phrasal Verb in the Word Down Found in the Novel Miror Image and Their Translation into Indonesia. Tesis S1 Denpasar: Fakultas Ilmu Budaya Universitas Udayana

Courtney, Rosemary. 1933. Longman Dictionary of Phrasal verbs. England: Longman House

Dixon, 2005. A Semantic Approach to English Grammar. New York: Oxford University
Dewi, Ni Wayan Puspa Kencana. 2006. Semantic and Syntactic Analysis of Phrasal Verbs. Tesis S1 Denpasar: Fakultas Ilmu Budaya Universitas Udayana

Quirk, Randolph et al. 1972. A Grammar of Contemporary English. Hongkong: Longman Group Limited

Quirk, Randloph and Sidney Greenbaum, 1973. A University Grammar of English. Hongkong: Longman Group Limited

Quirk, Randolph and Sidney Greenbaum, 1985. A Comprehensive Grammar of the English Language. Hongkong: Longman Group Limited

Newmark, Petter. 1988. A Textbook of Translation.New York: PrenticeHall International

Olson, Ana. 2014. Construction and Result: English Phrasal Verbs as Analyzed in Construction Grammar. Master Degree: The Faculty of Graduate Studies Master of Arts in Linguistics, Analytical Steam

Suanda, Gede, 2008. The Analysis of Phrasal Verb using Up and Down and their Translation in Indonesia with Reference to Sidney Sheldon Novel : A Stranger in The Miror. Tesis S1 Denpasar: Fakultas Ilmu Budaya Universitas Udayana

Subroto, D. Edi, 1992. Pengantar Metoda Penelitian Linguistik Struktural. Surakarta : Sebelas Maret University Press 
Spears, Richard A., 2005. Dictionary of American Idioms and Phrasal Verbs. United States of America: McGraw-Hill

Tulloch, Graham, 1990. English Grammar A Short Guide. Sydney: Sydney University Press

Venuti, 2000. The Translation Studies

Reader. London: Routledge

Windawati, 2015. Translation Method and Meaning Equivalence of Idiomatic Phrasal Verb in X-men First Class Movie. Tesis S1 Jakarta: Letters and Faculty State of Islamic University of Syarif Hidayatullah 